\title{
The ryegrass endophyte in a cool moist environment
}

\author{
J.P.J. EERENS. D.L. RYAN and K.B. MILLER
} AgResearch, Private Bag 50022, Gore

\begin{abstract}
A field grazing experiment studying the impact of the ryegrass endophyte (Acremonium lolii) in a cool moist environment, was carried out at AgResearch regional station in Gore Southland. Four types of pasture were established, high $(+\mathrm{E})$ and low (-E) endophyte ryegrass were sown with $(+C)$ or without $(-\mathrm{C})$ clover. The endophyte had no significant effect on the establishment of the pastures, neither did it affect total pasture production nor pasture composition. The presence of clover in pastures had a greater impact $(30 \%)$ on animal production than did the presence of endophyte $(6 \%)$. Mean daily weight gains over 3 years for lambs were $187,183,145$ and $132 \mathrm{~g} /$ day for $-E+C,+E+C$, $-\mathrm{E}$ and $+\mathrm{E}$ respectively. Lambs grazing endophytic pastures generally had higher levels of dags. However, ryegrass staggers occurred only in the year with below average summer rainfall. Not all the conditions necessary to induce ryegrass staggers are therefore required to expose livestock to other deleterious effects of endophyte. A detailed study into the environmental requirements for the production of endophyte related toxins is required. The findings reported here significantly differ from findings in summer dry areas.
\end{abstract}

Keywords Acremonium, animal production, Argentine stem weevil, endophyte, Lolium perenne, Southland, Trifolium repens

\section{Introduction}

The endophyte (Acremonium loiii) of perennial ryegrass has in recent years been identified as the causal agent for ryegrass staggers (Fletcher\&Harvey 198 1) andreduced liveweight gain in animals grazing pastures high in endophyte (Fletcher 1982; 1983). The same endophyte also provides perennial ryegrass with resistance to the pasture pest Argentine stem weevil (ASW) (Prestidge $\boldsymbol{e} t$ al. 1982). In the summer dry regions of New Zealand, an essential requisite for perennial ryegrass is the deterrence of ASW, which reaches densities capable of severely damaging ryegrass pastures lacking endophyte (Hunt 1990).
Lack of summer moisture also limits pasture production in these areas, resulting in hard grazing of perennial ryegrass pastures. This hard grazing (Keogh 1973) in combination with high levels of dead material and flowering stem (Fletcher 1982) has been associated with severe outbreaks of ryegrass staggers. The dramatic endophyte effects in Canterbury, have resulted in extensive studies of the endophyte problem in that area.

Little is know about endophyte effects in a cool moist environment. In recent years farmers have observed that lamb scouring has increased. At the same time the gap between potential and actual lamb liveweight gain has increased. with virtually no improvement in lamb performance on improved pastures. These occurrences coincide with an increased use of endophytic seed lines. A study of endophyte levels of old Southland pastures (> 50 years old) found levels ranging from $0 \%$ to $100 \%$ (Widdup \& Ryan, this proceedings). This longevity of low endophyte pastures is unique and its implications need to be researched. This paper reports on a study to examine the impact of endophyte on both pasture components and animal production in Southland, a region suited to white clover/perennial ryegrass pastures.

\section{Materials and methods}

Eight pastures were established in the spring of 1989 at the AgResearch research station at Gore, using a high ('wildtype' or common)(70\% infection) and a low $(0 \%$ infection) endophyte ( $+\mathrm{E}$ and $-\mathrm{E}$ respectively) line of Grasslands Nui perennial ryegrass sown at $18 \mathbf{~ k g} / \mathbf{h a}$. Four pastures were seeded with $3 \mathrm{~kg} / \mathrm{ha}(+\mathrm{C})$ of Grasslands Huia white clover and four remained as pure grass pastures; resulting in 2 replications of $2 \times 2$ treatments. Each pasture was subdivided into 8 subplots, to accommodate rotational grazing.

At sowing each pasture received $350 \mathrm{~kg} / \mathrm{ha}$ of $15 \%$ potassic-superphosphate (O-7-7-9) plus $100 \mathrm{~kg} / \mathrm{ha}$ of $\mathrm{N}$ as urea. An annual maintenance dressing of $250 \mathrm{~kg} / \mathrm{ha}$ molybdate superphosphate (0-9-O-11) was applied in year 2 and $325 \mathrm{~kg} / \mathrm{ha} 30 \%$ potassic superphosphate (06-14-8) in year 3 . The pure grass pastures also received $250 \mathrm{~kg} / \mathrm{ha}$ of $\mathrm{N}$ annually, applied in split applications on a 6-weekly basis from spring to autumn. Tomaintain the pure grass pastures free from clovers, Dicamba at $3 \mathrm{l} / \mathrm{ha}$ 
or Versatil (Clopyralid amine) at 1 1/ha was applied as required.

The trial area was rotationally graxed all yearround, with ewe mobs grouped together,. according to the endophyte status, over winter to accommodate a winter rotation. Rotation length varied from 4-weekly (1 week grazing followed by 3 weeks' regrowth) in spring to $\mathbf{5}$ 6 weekly in summer. In the first year, each pasture was grazed by 30 lambs from February to May. In the following two years each pasture was continuously stocked with 20 ewes/ha, while lambs were on the pastures from September to March. Ewes lambed on the pastures and only male (cryptorchid) lambs were maintained from weaning onward. Ewe lambs were replaced where necessary with cryptorchid lambs from elsewhere. Lamb numbers were adjusted frequently to achieve similar feed allowances on each pasture. A minimum of 10 lambs were measured and continuously grazed on each pasture. Target pre grazing mass was $2500 \mathrm{~kg}$ DM/ ha, with a target post grazing mass of $1200-1500 \mathrm{~kg}$ DM/ ha. Residues were grazed down to $800-1000 \mathrm{~kg}$ DM/ha by the ewes, with excess residues being topped to achieve similar levels of residue on all eight pastures.

Lamb growth rates were monitored by fortnightly weighing at which time the lambs were scored for ryegrass staggers and level of dags. Ryegrass staggers scoring was according to the increasing scale of severity described by Keogh (1973). Ryegrass staggers induction was attempted by forcing the animals to run over a distance of approximately $400 \mathrm{~m}$. Pasture growth rates were assessed by monthly cutting of exclusion cages and herbage mass was measured, using a pasture probe, before and after each grazing period. Pasture composition was determined by dissection of herbage samples before and after grazing. Duriig October, December, February and July each year, 60 cores $50 \mathrm{~mm}$ in diameter were removed from each pasture and numbers of ryegrass tillers, clover growing points and stolon length and weight were measured.

\section{Results}

Weather information for the Gore trial site

Half the rain of December 1989 fell on one day which resulted in high levels of runoff. The summer of 1989/ 90 was dryer than the following summers and at the same time warmer especially in February. The two following summers were wetter than average with lower than average temperatures in October and November of 1991.

\section{Pasture production}

Total pasture production was not affected by the endophyte, nor did the endophyte have a significant effect on pasture composition (Table 2). Ryegrass yields were similar in the corresponding endophyte and non endophyte treatments. Clover proportions were around $30 \%$ for both the $+\mathrm{E}+\mathrm{C}$ and $-\mathrm{E}+\mathrm{C}$ treatments, even though in absolute terms, there was a higher clover production in the $-\mathrm{E}+\mathrm{C}$ treatment.

The mean levels of pre and post grazing herbage mass were similar with no significant differences between treatments. Intakes (the difference between the pre- and post-grazing herbage mass) were slightly higher for the plus clover treatments in comparison to equivalent non clover treatments, which was also reported by Hughes (1983). Pasture allowances were sufficient to allow maximum daily weight gains (Jagusch et al. 1979).

No significant differences were recorded between the treatments for either number of ryegrass tillers or number of clover growing points (Table 3 ). The presence of clover had a greater impact on the number of ryegrass tillers than the presence of endophyte. The endophyte had no effect on changes in either tiller numbers or number of clover growing points over time. The stolon length and stolon weight figures were very similar to the clover growing point comparison.

Table 1 Mean monthly temperatures and total monthly rainfall, from October to March at Gore

\begin{tabular}{|c|c|c|c|c|c|c|c|c|}
\hline & \multicolumn{2}{|c|}{$1989 / 90$} & \multicolumn{2}{|c|}{$1990 / 91$} & \multicolumn{2}{|c|}{1991192} & \multicolumn{2}{|c|}{$1951 \cdot 1980$} \\
\hline & $\begin{array}{c}\text { Temp } \\
{ }^{\circ} \mathrm{C}\end{array}$ & $\begin{array}{l}\text { Rain } \\
\text { (mm) }\end{array}$ & $\begin{array}{c}\text { Temp } \\
{ }^{\circ} \mathrm{C}\end{array}$ & $\begin{array}{l}\text { Rain } \\
\text { (mm) }\end{array}$ & $\begin{array}{c}\text { Temp } \\
{ }^{\circ} \mathrm{C}\end{array}$ & $\begin{array}{l}\text { Rain } \\
(\mathrm{mm})\end{array}$ & $\begin{array}{l}\text { Temp } \\
{ }^{\circ} \mathrm{C}\end{array}$ & $\begin{array}{l}\text { Raln } \\
\text { (mm) }\end{array}$ \\
\hline Oct & 11.0 & 53 & 10.4 & 66 & 9.5 & 66 & 10.1 & 70 \\
\hline $\begin{array}{l}\text { NOV } \\
\text { Dec }\end{array}$ & 12.1 & $\begin{array}{r}77 \\
129\end{array}$ & $\begin{array}{l}11.7 \\
128\end{array}$ & $\begin{array}{r}42 \\
130\end{array}$ & $\begin{array}{c}9.6 \\
123\end{array}$ & $\begin{array}{r}99 \\
105\end{array}$ & $\begin{array}{l}11.6 \\
13.4\end{array}$ & $\begin{array}{l}76 \\
83\end{array}$ \\
\hline Jan & $\begin{array}{l}12.8 \\
14.3 \\
15.6\end{array}$ & $\begin{array}{c}129 \\
61 \\
65\end{array}$ & $\begin{array}{l}12.8 \\
14.4 \\
127\end{array}$ & $\begin{array}{l}130 \\
123 \\
131\end{array}$ & $\begin{array}{l}12.3 \\
14.5 \\
12 .\end{array}$ & $\begin{array}{c}105 \\
\text { so } \\
113\end{array}$ & $\begin{array}{l}13.4 \\
14.3 \\
14.2\end{array}$ & $\begin{array}{r}83 \\
100 \\
59\end{array}$ \\
\hline $\begin{array}{l}\text { red } \\
\text { Mar }\end{array}$ & $\begin{array}{l}15.6 \\
12.7\end{array}$ & $\begin{array}{l}65 \\
88\end{array}$ & $\begin{array}{l}12.7 \\
13.7\end{array}$ & $\begin{array}{r}131 \\
39\end{array}$ & $\begin{array}{l}12.0 \\
11.7\end{array}$ & $\begin{array}{r}113 \\
84\end{array}$ & $\begin{array}{l}14.2 \\
12.9\end{array}$ & $\begin{array}{l}59 \\
88\end{array}$ \\
\hline
\end{tabular}


Table 2 Mean annual pasture production figures of two complete years from April 1990 onwards (kg DM/ha)

\begin{tabular}{lcccc}
\hline & total & Ryegrass & Clover & Wead \\
E+C & 18100 & 10800 & 5400 & 1900 \\
$+\mathrm{E}+\mathrm{C}$ & 16700 & 10800 & 4700 & 1400 \\
$-\mathrm{E}$ & 14100 & 11500 & & 2600 \\
$+\mathrm{E}$ & 14000 & 12200 & & 1800 \\
isd $(5 \%)$ & 1610 & 1580 & 780 & 2350 \\
\hline
\end{tabular}

$+E$ and $-E$, high and low endophyte respectively

$+C_{1}$ perennlal ryegrasswhile clover sward

Table 3 Mean number $\mathrm{m}^{2}$ of tilless and clover growing points.

\begin{tabular}{lcccc}
\hline & \multicolumn{2}{c}{$\begin{array}{c}\text { Ryegrass } \\
\text { tIllers }\end{array}$} & \multicolumn{2}{c}{$\begin{array}{c}\text { Clover } \\
\text { polnts }\end{array}$} \\
& $1990 / 91$ & $1991 / 92$ & $1990 / 91$ & $1991 / 92$ \\
$-E+C$ & 4670 & 5870 & 4950 & 9520 \\
$+E+C$ & 5890 & 6210 & 4510 & 3340 \\
$-E$ & 7950 & 6860 & & \\
$+E$ & 9400 & 7020 & & \\
isd $(5 \%)$ & 4110 & 1760 & 940 & 390 \\
\hline
\end{tabular}

Animal production

The major factor in animal production was the presence of clover (Table 4). The 30\% higher weight gains for animals grazing on a pasture with $30 \%$ clover is not unexpected. Lamb weight gains on a perennial ryegrass/ white clover pasture increase with an increased clover component (Brown 1990). There was a significant difference in animal production between comparable clover and non clover treatments in all but one instance.

Ryegrass staggers occurred only in the summer of 1989 and was worse in the follow animals than the lambs grazing the fresh regrowth. This supports earlier observation that the severity of ryegrass staggers is related to the closeness of grazing (Keogh 1973). Only lambs grazing the endophytic pastures showed signs of ryegrass staggers with those grazing the $+\mathrm{E}+\mathrm{C}$ treatment being less affected than those grazing the $+\mathrm{E}$ treatment. The level of dags on the lambs was generally highest on the high endophyte pastures

\section{Discussion}

The similar total pasture production levels of endophytic and non endophytic pastures arc in contrast to fimdings by Latch $\boldsymbol{e t}$ al. (1985) and Arechavaleta $\boldsymbol{e t}$ al. (1989), who recorded $38 \%$ and $\mathbf{5 0} \%$ respectively higher production by endophytic plants over non endophytic plants. Thecoolmoist Southland climatemay be a major contributing factor in these similar production levels. Summer droughts are not common as rainfall is generally highest over the summer months. The moderate summer temperatures are not conductive for a speedy development of the ASW (Barker 1988). which based on Barker (1988) completes approximately one full generation per year in Southland. Major tiller damage caused by the ASW generally occurs from the second generation onwards (Hunt 1990).

The similar ratios of clover in both $-\mathrm{E}+\mathrm{C}$ and $+\mathrm{E}+\mathrm{C}$ treatments is in contrast to findings by Sutherland \& Hoglund (1989) and Stevens \& Hickey (1990) who report a clover depressing action by the endophyte. In both cases was the reduced clover ratio in endophytic pastures linked with a higher total production of those pastures. A significant level of tiller damage in non endophytic pastures resulting from ASW attack may have opened up those non endophytic pastures thus providing the clover with more growing space. Low levels of tiller damage have been observed regardless of endophyte status in the Gore experiment which may explain the similar clover ratios.

The differences in lamb liveweight gains between the $-\mathrm{E}+\mathrm{C}$ and $+\mathrm{E}+\mathrm{C}$ treatments underestimate an endophyte effect, as the clover intake of lambs was about $45 \%$ of their total intake. Therefore an endophyte effect on animal production shows up best in the comparison between the non clover treatments. The $-\mathbf{E}$ treatment significantly outperformed the $+\mathrm{E}$ treatment in most instances. The similar total pasture production figures combined with a slightly higher proportion of ryegrass in the $+\mathrm{E}$ treatment, indicate that there was an endophyte effect on animal production. The factor causing this is likely to be mobile in the plant as animals had access to adequate leafy herbage with limited intakes of basal

Table 4 Weaning weights of the lambs and daily weight gains for cryptorchid lambs.

\begin{tabular}{|c|c|c|c|c|c|c|}
\hline & \multicolumn{3}{|c|}{ Weaning weights(kg) } & \multicolumn{3}{|c|}{ Daily weight gains ( $($ day) } \\
\hline & 1990 & 1991 & $1989 / 90$ & $1990 / 91$ & $1991 / 92$ & Mean \\
\hline$-E+C$ & 23.8 & 24.5 & 180 & 177 & 205 & 187 \\
\hline$+E+C$ & 21.7 & 23.5 & 181 & 161 & 227 & 183 \\
\hline$-E$ & 22.5 & 19.5 & 147 & 119 & 170 & 145 \\
\hline$+E$ & 19.7 & 18.5 & 148 & 100 & 148 & 132 \\
\hline Isd (5\%) & 1.8 & 1.2 & 17.9 & 14.4 & 17.0 & \\
\hline
\end{tabular}


material. An ergot alkaloid, ergovaline, has been identified as a causal agent for liveweight gain reductions in tall fescue (Festuca arundinacea) (Belesky et 1.1988).

The chemical lolitrem B has been identified as the causal agent for ryegrass staggers (Gallagher et al. 1981). The predominant occurrence of ryegrass staggers in animals forced to graze basal material indicate that lolitrem B is concentrated in the base of the plant, similar to where the endophyte is located (Musgrave 1984) and is rather immobile. The lack of ryegrass staggers in years when an endophyte effect on liveweight gains was recorded, point to a difference in environmental requirements for the production of the relevant chemicals.

Conclusions from this trial in a cool moist environment:

1. The endophyte had no significant effect on plant growth.

2. Theendophyte had a significant effect on animal health and production.

3. The presence of clover in the sward minimised endophyte effects.

\section{REFERENCES}

Arechavaleta. M.; Bacon, C.W.; Hoveland, C.S.; Radcliffe, D.E. 1989. Effect of the tall fescue endophyte on plant response to environmental stress. Agronomy journal 81: 83-90.

Barker, G.M. 1988. Effect of temperature on development and survival of Argentine stem weevil (Listronotus bonariensis) immature stages. New Zealand journal of zoology 15: 387-390.

Belesky. D.P.; Stuedemann. J.A.; Platmer, R.D.; Wilkinson S.R 1988. Ergopeptine Alkaloids in grazed tall fescue. Agronomy journal 80: 209-212.

Brown, C. 1990. An integrated herbage system for Southland and South Otago. Proceedings of the New Zealand Grassland Association 52: 119. 122.

Fletcher, L.R. 1982. Observations of ryegrass staggers in weaned lambs grazing different ryegrass pastures. New Zealand journal of experimental agriculture 10: 203-207.

Fletcher, L.R. 1983. Effects of presence of Lolium endophyte on growth rates of weaned lambs, growing on to hoggets, on various ryegrasses. Proceedings of the New Zealand Grassland Association 44: 237-239.
Fletcher, L.R.; Harvey, I.C. 1981. An association of a Lolium endophyte with ryegrass staggers. New Zealand veterinury journal 29: 185-186.

Gallagher, R.T.; White. E.P.; Mortimer P.H. 1981. Ryegrass staggers: Isolation of potent neurotoxins Lolitrem A and Lolitrem B from staggers producing pastures. New Zealand veterinury journal 29: 189-190.

Hughes, T.P. 1983. Grazing intake. pp. 17-21. In. Familton A.S. (ed.). Lamb growth. Animal industries workshop Lincoln College, Farmers' handbook.

Hunt. W.F. 1990. Annual variations in the severity of attack by Argentine stem weevil on perennial ryegrass. Proceedings of the New Zealand Grassland Association 52: 221-225.

Jagusch, K.T.; Rattray, P.V.; Oliver; T.W.; Cox, N.R. 1979. The effect of herbage yield and allowance on growth and carcass characteristics of weaned lambs. Proceedings New Zealand Society of Animal Production 39: 254-259.

Kwgh, R.G. 1973. Induction and prevention of ryegrass staggers in sheep. New Zealand journal of experimental agriculture 1: 55-57.

Latch, G.C.M.; Hunt. W.F.; Musgrave. D.R. 1985. Endophytic fungi affect growth of perennial ryegrass. New Zealand journal of agricultural research 28: 165-168.

Musgrave. D.R. 1984. Detection of an endophytic fungus of Lolium perenne using enzyme-linked immunosorbent assay (ELISA). New Zealand journal of agricultural research 27: 283-288.

Prestidge, R.A.; Pottinger, R.P.; Barker, G.M. 1982. An association of Lolium endophyte with ryegrass resistance to Argentine stem weevil. Proceedings 35th New Zealand Weed and Pest Control Conference: 119-122.

Stevens, D.R.; Hickey,M.J. 1990. Effectsofendophytic ryegrass on the production of ryegrass/white clover pastures. Proceedings of the Ist International Symposium on Acremonium Grass interactions: $58-61$.

Sutherland, B.L.; Hoglund, J.H. 1989. Effects of ryegrass containing the endophyte (Acremonium lolii) on the performance of associated white clover and subsequent crops. Proceedings of the New Zealand Grassland Association 50: 265-269.

Widdup, K.H.; Ryan, D.L. 1992. Forage potential of wild populations of perennial ryegrass collected from Southern New Zealand farms. Proceedings of the New Zealand Grassland Association 54 (ii Press) 